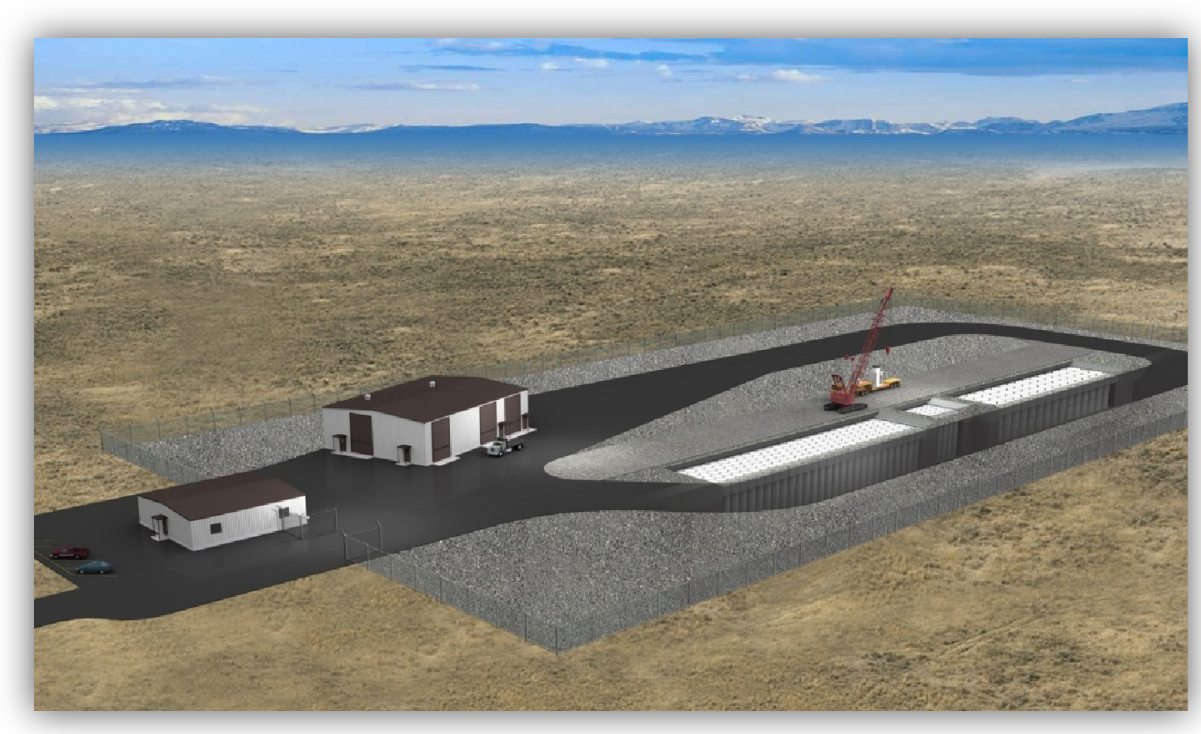

\title{
Remote-Handled Low-Level Waste Disposal Project Code of Record
}

June 2012

The INL is a U.S. Department of Energy National Laboratory operated by Battelle Energy Alliance 


\section{DISCLAIMER}

This information was prepared as an account of work sponsored by an agency of the U.S. government. Neither the U.S. government nor any agency thereof, nor any of their employees, makes any warranty, expressed or implied, or assumes any legal liability or responsibility for the accuracy, completeness, or usefulness, of any information, apparatus, product, or process disclosed, or represents that its use would not infringe privately owned rights. References herein to any specific commercial product, process, or service by trade name, trade mark, manufacturer, or otherwise, does not necessarily constitute or imply its endorsement, recommendation, or favoring by the U.S. government or any agency thereof. The views and opinions of authors expressed herein do not necessarily state or reflect those of the U.S. government or any agency thereof. 
INL/EXT-10-20044

Revision 4

\section{Remote-Handled Low-Level Waste Disposal Project Code of Record}

June 2012

Idaho National Laboratory Idaho Falls, Idaho 83415

http://www.inl.gov

Prepared for the

U.S. Department of Energy

Office of Nuclear Energy

Under DOE Idaho Operations Office

Contract DE-AC07-05ID14517 



\title{
Remote-Handled Low-Level Waste Disposal Project Code of Record
}

\author{
INL/EXT-10-20044
}

June 2012

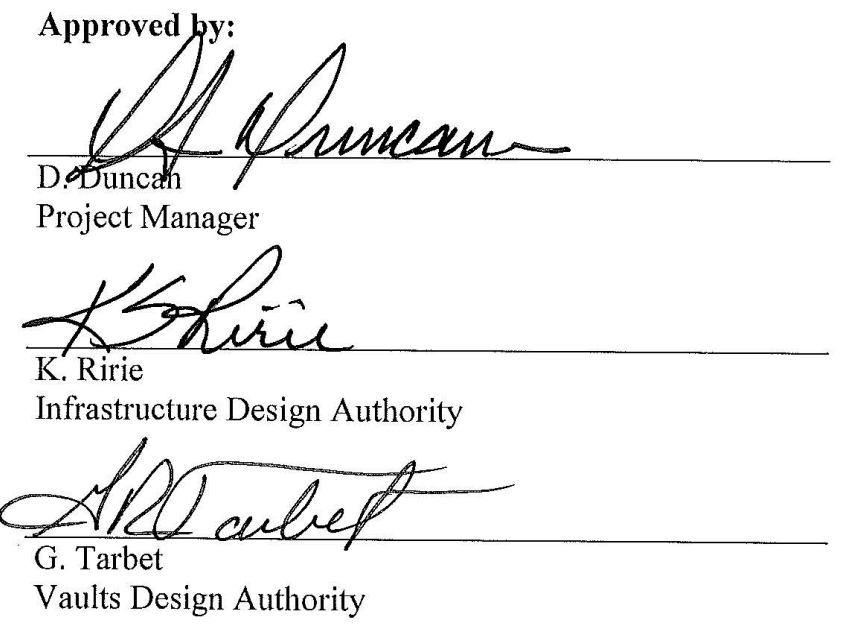

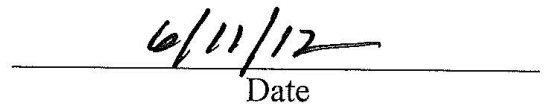

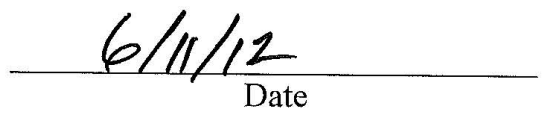

$\frac{6 / 1 / 1 / 12}{\text { Date }}$ 



\begin{abstract}
The Remote-Handled Low-Level Waste (LLW) Disposal Project addresses an anticipated shortfall in remote-handled LLW disposal capability following cessation of operations at the existing facility, which will continue until it is full or until it must be closed in preparation for final remediation of the Subsurface Disposal Area (approximately at the end of Fiscal Year 2017). Development of a new onsite disposal facility will provide necessary remote-handled LLW disposal capability and will ensure continuity of operations that generate remote-handled LLW. This report documents the Code of Record for design of a new LLW disposal capability. The report is owned by the Design Authority, who can authorize revisions and exceptions. This report will be retained for the lifetime of the facility.
\end{abstract}




\section{CONTENTS}

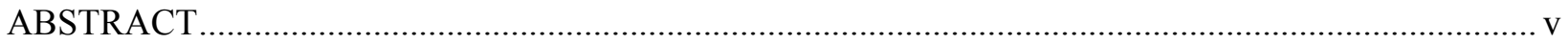

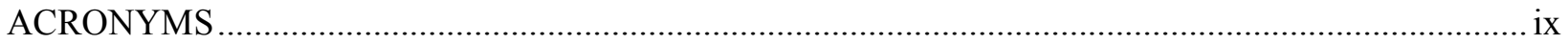

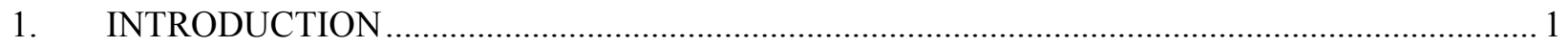

2. REGULATIONS, EXECUTIVE ORDERS, AND DEPARTMENT OF ENERGY

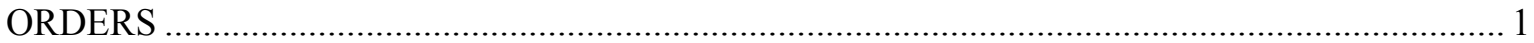

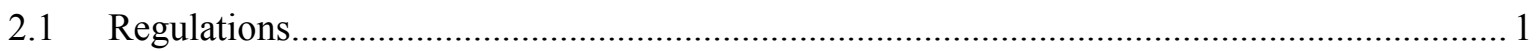

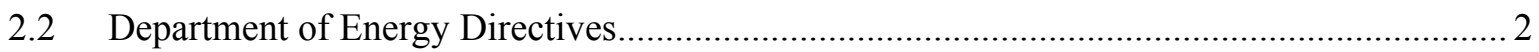

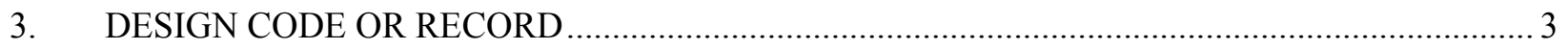

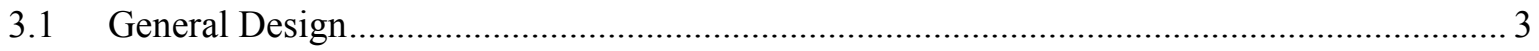

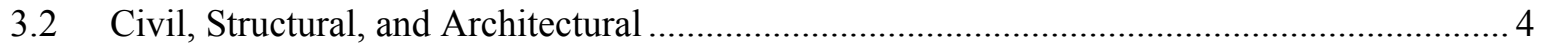

3.3 Mechanical; Heating, Ventilating, and Air Conditioning; Piping ........................................ 5

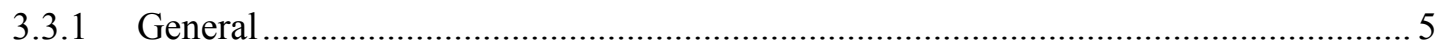

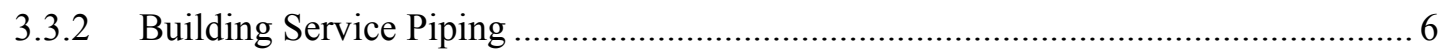

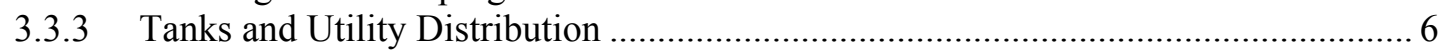

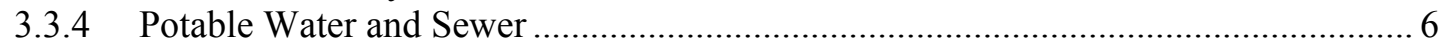

3.3.5 Heating, Ventilating, and Air Conditioning and Ducting ....................................... 7

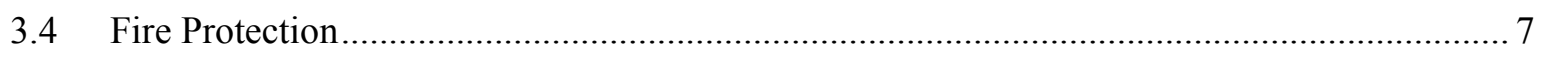

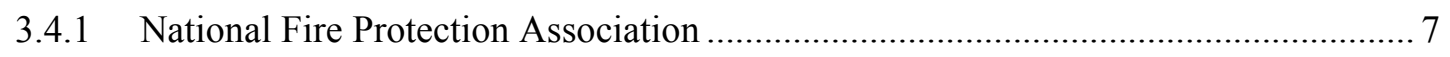

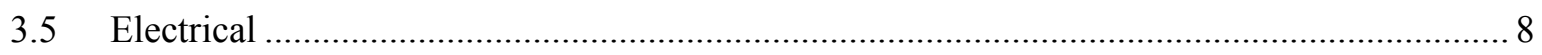

3.5.1 General Facility Electrical Codes and Standards ................................................. 8

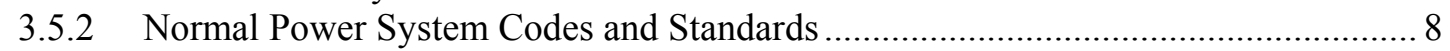

3.5.3 Lighting System Codes and Standards........................................................... 9

3.5.4 Grounding System Codes and Standards ....................................................... 9

3.5.5 Lightning Protection System Codes and Standards ............................................... 9

3.5.6 Telephone System Codes and Standards............................................................ 9 


\section{ACRONYMS}

ACI American Concrete Institute

AISC American Institute of Steel Construction

ANSI American National Standards Institute

ASCE American Society of Civil Engineers

ASHRAE American Society of Heating, Refrigeration, and Air Conditioning Engineers

AWS American Welding Society

CFR Code of Federal Regulations

DOE Department of Energy

IDAPA Idaho Administrative Procedures Act

IEEE Institute of Electrical and Electronics Engineers

INL Idaho National Laboratory

LLW low-level waste

NFPA National Fire Protection Association

SJI Steel Joist Institute 


\section{Remote-Handled Low Level Waste Disposal Project Code of Record}

\section{INTRODUCTION}

Remote-handled low-level waste (LLW) in the form of activated metals is generated from operations at Idaho National Laboratory's (INL's) Naval Reactors Facility and the Advanced Test Reactor Complex. Activated metals also are planned to be generated from new missions and from segregation and treatment (as necessary) of remote-handled scrap and waste currently stored at the Materials and Fuels Complex. Remote-handled LLW ion-exchange resins are generated from operations at the Naval Reactors Facility and Advanced Test Reactor Complex. Disposal of remote-handled LLW in the disposal vaults of the existing INL waste disposal facility is planned through the end of Fiscal Year 2017. Continued remote-handled LLW disposal capability is critical to continuing the U.S. Department of Energy (DOE) Office of Nuclear Energy, Science, and Technology and Office of Naval Reactors missions conducted at INL. A new onsite disposal facility will be constructed to provide uninterrupted, remote-handled LLW disposal capability.

Consistent with DOE Order 413.3B, DOE Order 420.1B (Change 1), and DOE-STD-1189 for nuclear facilities, a project Code of Record has been developed. This Code of Record will be maintained throughout the Critical Decision process and for the remainder of the nuclear facility's life-cycle. The Code of Record will serve as the management tool and source for the set of requirements that are used to design, construct, operate and decommission the RH-LLW facility over its lifespan. This Code of Record was initiated during Conceptual Design and revised during the design-build procurement process to reflect updated codes and standards cited in SPC-1437, "Design-Build-Operate Performance Specification for the Remote-Handled Low-Level Waste Disposal Project."

\section{REGULATIONS, EXECUTIVE ORDERS, AND DEPARTMENT OF ENERGY ORDERS}

Applicable regulations, executive orders, and DOE orders are summarized in the following subsections. These regulations, executive orders, and DOE orders should be reviewed and finalized against the current INL contract prior to preliminary or final design.

\subsection{Regulations}

- 10 CFR 434, 2007, "Energy Conservation Voluntary Performance Standards for New Buildings; Mandatory for Federal Buildings," Code of Federal Regulations, Office of the Federal Register, December 2007.

- 10 CFR 830, "Nuclear Safety Management," Code of Federal Regulations, Office of the Federal Register.

- 10 CFR 835, 2002, “Occupational Radiation Protection," Code of Federal Regulations, Office of the Federal Register, February 2002.

- 10 CFR 851, "Worker Safety and Health Program," Code of Federal Regulations, Office of the Federal Register.

- 10 CFR Part 860, 2004, “Trespassing on Administration Property," Code of Federal Regulations, Office of the Federal Register, March 2004.

- 29 CFR 1910, 2010, “Occupational Safety and Health Standards," Code of Federal Regulations, Office of the Federal Register, June 2010. 
- 29 CFR 1926, 2010, "Safety and Health Regulations for Construction," Code of Federal Regulations, Office of the Federal Register, August 2010.

- 41 CFR Part 101, 2002, "Federal Property Management Regulation," Code of Federal Regulations, Office of the Federal Register, December 2002.

- Executive Order 13423, "Strengthening Federal Environmental, Energy, and Transportation Management," 2007.

- IDAPA 02.06.22, "Noxious Weed Rules," Idaho Administrative Procedures Act, Idaho Department of Agriculture.

- IDAPA 07.02.06, "Rules Concerning Uniform Plumbing Code," Idaho Administrative Procedures Act, Division of Building Safety.

- IDAPA 07.07.01, "Rules Governing Installation of Heating, Ventilation, and Air Conditioning Systems," Idaho Administrative Procedures Act, Idaho Division of Building Safety.

- IDAPA 58.01.01, "Rules for the Control of Air Pollution in Idaho," Idaho Administrative Procedures Act, Idaho Department of Environmental Quality, July 1, 2007.

- IDAPA 58.01.01.201, "Permit to Construct Required," Idaho Administrative Procedures Act, Idaho Department of Environmental Quality, April 11, 2006.

- IDAPA 58.01.01.202, “Application Procedures," Idaho Administrative Procedures Act, Idaho Department of Environmental Quality, July 1, 2002.

- IDAPA 58.01.08, "Idaho Rules For Public Drinking Water Systems," Idaho Administrative Procedures Act, Idaho Department of Environmental Quality.

- IDAPA 58.01.16, "Wastewater Rules," Idaho Administrative Procedures Act, Idaho Department of Environmental Quality.

\subsection{Department of Energy Directives}

- DOE Order 226.1B, “Implementation of Department of Energy Oversight Policy,” U.S. Department of Energy.

- DOE Order 413.3B, "Program and Project Management for the Acquisition of Capital Assets," U.S. Department of Energy.

- DOE Order 414.1C, “Quality Assurance,” U.S. Department of Energy.

- DOE Order 420.1B, "Facility Safety," Change 1, U.S. Department of Energy.

- DOE Order 425.1D, "Verification of Readiness to Start Up or Restart Nuclear Facilities," U.S. Department of Energy.

- DOE Order 426.2, "Personnel Selection, Training, and Certification Requirements for DOE Nuclear Facilities," U.S. Department of Energy.

- DOE Order 430.2B, "Renewable Energy and Transportation Management," U.S. Department of Energy.

- DOE Order 433.1B, "Maintenance Management Program for DOE Nuclear Facilities,” U.S. Department of Energy.

- DOE Order 435.1, "Radioactive Waste Management," Change 1, U.S. Department of Energy.

- DOE Order 450.1A, “Environmental Protection Program”, U.S. Department of Energy. 
- DOE Order 458.1, "Radiation Protection of the Public and the Environment," Change 1 and Change 2, U.S. Department of Energy.

- DOE Order 460.1C, "Packaging and Transportation Safety," U.S. Department of Energy.

- DOE Order 471.6, "Information Security," U.S. Department of Energy.

- DOE Order 473.3, "Protection Program Operations," U.S. Department of Energy.

- DOE-STD-1020-02, "Natural Phenomena Hazards Design and Evaluation Criteria for Department of Energy Facilities," Change 1, U.S. Department of Energy.

- DOE-STD-1021-93, "Natural Phenomena Hazards Performance Categorization Guidelines for Structures, Systems, and Components," Change 1, U.S. Department of Energy.

- DOE-STD-1027-92, "Hazard Categorization and Accident Analysis Techniques for Compliance with DOE Order 5480.23, Nuclear Safety Analysis Reports," U.S. Department of Energy, December 1992 (including Change 1, September 1997).

- DOE-STD-1028-09, "Human Performance Improvement Handbook,” U.S. Department of Energy.

- DOE-STD-1073-03, “Configuration Management Program,” U.S. Department of Energy.

- DOE-STD-1090-11, “Hoisting and Rigging,” U.S. Department of Energy.

- DOE-STD-1140-01, "Human Factor/Ergonomics Handbook for the Design for Ease of Maintenance," U.S. Department of Energy.

- DOE-STD-1189-2008, “Integration of Safety into the Design Process," U.S. Department of Energy.

- DOE-STD-3009-94, "Preparation Guide for U.S. Department of Energy Nonreactor Nuclear Facility Documented Safety Analyses," Change Notice 3, U.S. Department of Energy, July 1994 (including Change 1, January 2000; Change 2, April 2002, and Change 3, March 2006).

- DOE-STD-3024-11, “Content of System Design Descriptions,” U.S. Department of Energy.

\section{DESIGN CODE OR RECORD}

The Remote-Handled LLW Project design criteria for facility modifications or new construction are summarized in the following subsections. Edition dates are based on a Fiscal Year 2013 design schedule. If design is delayed, edition dates should reflect the latest current edition date at the start of preliminary or final design. Additional codes and standards may be mandated by higher-level documents and are not listed. This report will be reviewed and finalized at the start of preliminary or final design to assess required updates or changes.

\subsection{General Design}

- International Building Code, 2012 Edition.

- NFPA 1, "Fire Prevention Code," 2012 Edition.

- National Fire Protection Association (NFPA) 101, "Life Safety Code," 2012 Edition.

- International Mechanical Code (IMC), 2012 Edition.

- NFPA 70, "National Electric Code (NEC)," 2011 Edition.

- INL-STD-139, “INL Engineering Standards,” Idaho National Laboratory.

- DOE Order 420.1B, "Facility Safety,” Change 1, U.S. Department of Energy. 
- DOE Order 430.2B, "Renewable Energy and Transportation Management," U.S. Department of Energy.

- DOE Order 460.1C, "Packaging and Transportation Safety," U.S. Department of Energy.

- DOE Manual 470.4-2A, "Physical Protection," U.S. Department of Energy.

- DOE Manual 470.4-4A, "Information Security Manual," Change 1, U.S. Department of Energy.

- ASME NQA-1-2008, 1a-2009, "Quality Assurance Requirements for Nuclear Facility Applications," American Society of Mechanical Engineers.

\subsection{Civil, Structural, and Architectural}

- AASHTO, "Policy on Geometric Design of Highways and Streets (Green Book)," 6th Edition

- AASHTO VLVLR-1, "Guidelines for Geometric Design of Very Low-Volume Local Roads," American Association of State Highway Transportation Officials, First Edition.

- SSHC, "Standard Specifications for Highway Construction," State of Idaho Transportation Department, Division of Highways, 2004 Edition.

- CMAA, "Crane Manufacturers Association of America.

- DOE Order 420.1B, “Facility Safety,” Change 1, U.S. Department of Energy.

- DOE Order 450.1A, “Environmental Protection Program”, U.S. Department of Energy.

- DOE-STD-1020, "Natural Phenomena Hazards Design and Evaluation Criteria for Department of Energy Facilities," U.S. Department of Energy.

- INL Welding Manual.

- International Building Code, 2012 Edition.

- ADAAG, “Americans with Disabilities Act Accessibility Guidelines,” 2004 Edition.

- American Society of Civil Engineers (ASCE)/Structural Engineering Institute 43, "Seismic Design Criteria for Structures, Systems, and Components in Nuclear Facilities," 2005 Edition.

- ASCE 7, "Minimum Design Loads for Buildings and Other Structures," 2010 Edition.

- American Concrete Institute (ACI) 201.2R, "Guide to Durable Concrete," 2008 Edition.

- ACI 301, "Specifications for Structural Concrete," 2010 Edition.

- ACI 318, "Building Code Requirements for Structural Concrete," 2008 Edition.

- ACI 349, "Code Requirements for Nuclear Safety Related Concrete Structures," 2006 Edition.

- ACI 530, "Building Code Requirements for Masonry Structures," 2008 Edition.

- ACI 530.1, "Specifications for Masonry Structures," 2008 Edition.

- American Institute of Steel Construction (AISC) SCM, "Steel Construction Manual," Thirteenth Edition.

- AISC M011, "Manual of Steel Construction, Allowable Stress Design,” 1980.

- AISC 341, "Seismic Provisions for Structural Steel Buildings," 2010 Edition.

- AISC 360, "Specification for Structural Steel Buildings," 2010 Edition.

- American Iron and Steel Institute (AISI) S100-S214, "North American Specification for the Design of Cold-formed Steel Structural Members," 2007 Edition. 
- American National Standards Institute (ANSI)/American Nuclear Society 2.26, "Categorization of Nuclear Facility Structures, Systems and Components for Seismic Design," 2004 Edition.

- ANSI/NC 1.0, "Standard for Noncomposite Steel Floor Deck," Steel Deck Institute, 2006 Edition.

- ANSI/RD 1.0, "Standard for Steel Roof Deck," Steel Deck Institute, 2006 Edition.

- ASCE 5, "Building Code Requirements for Masonry Structures," 2011 Edition.

- ASCE 6, "Specifications for Masonry Structures," 2011 Edition.

- ASCE 7, "Minimum Design Loads for Buildings and Other Structures," 2010 Edition.

- ASCE 8, "Standard Specification for the Design of Cold-formed Stainless Steel Structural Members," 2008 Edition.

- ASCE/Structural Engineering Institute 43, "Seismic Design Criteria for Structures, Systems, and Components in Nuclear Facilities," 2005 Edition.

- American Society of Mechanical Engineers NOG-1, "Rules for Construction of Overhead and Gantry Cranes (Top Running Bridge, Multiple Girder)," 2004 Edition.

- American Society for Testing Materials (ASTM) C 857, "Standard Practice for Minimum Structural Design Loading for Underground Precast Concrete Utility Structures," 2012 Edition.

- $\quad$ ASTM C 1562, "Standard Guide for Evaluation of Materials Used in Extended Service of Interim Spent Nuclear Fuel Dry Storage Systems," 2010 Edition.

- American Welding Society (AWS) D1.1, "Structural Welding Code - Steel," 2004 Edition.

- AWS D1.2, "Structural Welding Code - Aluminum," 2008 Edition.

- AWS D1.3, "Structural Welding Code - Sheet Steel," 1998 Edition.

- AWS D1.4, "Structural Welding Code - Reinforcing Steel," 1998 Edition.

- PCI MNL 120, "Prestressed Concrete Institute Design Handbook for Precast and Prestressed Concrete," 2004.

- $\quad$ PCI MNL 116, "Manual for Quality Control for Plant and Production of Precast and Prestressed Concrete," 1999.

- Steel Joist Institute (SJI)-CJ-1.0, "Standard Specification for Composite Steel Joists, CJ-series," 2010 Edition.

- SJI-JG-1.1, "Standard Specification for Joist Girders," 2010 Edition.

- SJI-K-1.1, "Standard Specification for Open Web Steel Joists, K-series,” 2010 Edition.

- SJI-LH/DLH-1.1, "Standard Specification for Longspan Steel Joists, LH-series and Deep Longspan Steel Joists," DLH-series, 2010 Edition.

- DOE HDBK-3010, “Airborne Release Fractions/Rates and Respirable Fractions for Nonreactor Nuclear Facilities," U.S. Department of Energy, December 1994.

\subsection{Mechanical; Heating, Ventilating, and Air Conditioning; Piping}

\subsubsection{General}

- INL Welding Manual

- IMC, "International Mechanical Code," 2012 Edition. 
- IBC, "International Building Code," 2012 Edition.10 CFR 434, "Energy Conservation Voluntary Performance Standards for New Buildings; Mandatory Energy Conservation" Code of Federal Regulations, Office of the Federal Register, December 2007.

- DOE Order 430.2B, "Renewable Energy and Transportation Management," U.S. Department of Energy.

- American Society of Heating, Refrigeration, and Air Conditioning Engineers (ASHRAE) 90.1, ANSI/IESNA Standard 90.1-2007, "Energy Standard for Buildings Except Low-Rise Residential Buildings," 2007 Edition.

- NFPA 54, "National Fuel Gas Code," 2011 Edition.

\subsubsection{Building Service Piping}

- American Society of Mechanical Engineers A13.1, "Scheme for Identification of Piping Systems," 2007.

- American Society of Mechanical Engineers B31.9, "Building Service Piping,” 2008.

- American Water Works Association, "Cross Connection Control Manual, Accepted Procedure and Practice," Pacific Northwest Section of American Water Works Association.

- IDAPA 07.02.06, "Rules Concerning Uniform Plumbing Code," Idaho Administrative Procedures Act, Idaho Department of Environmental Quality, Division of Building Safety.

- IDAPA 07.07.01, "Rules Governing Installation of Heating, Ventilation, and Air Conditioning Systems," Idaho Administrative Procedures Act, Idaho Department of Environmental Quality, Division of Building Safety.

- IDAPA 58.01.08, "Idaho Rules for Public Drinking Water Systems," Idaho Administrative Procedures Act, Idaho Department of Environmental Quality.

- IDAPA 58.01.16, "Wastewater Rules," Idaho Administrative Procedures Act, Idaho Department of Environmental Quality.

- Uniform Plumbing Code, 2003 Edition.

\subsubsection{Tanks and Utility Distribution}

- American Water Works Association D100, "Welded Carbon Steel Tanks for Water Storage," American Water Works Association," 2005 Edition with 2007 Errata.

- National Association of Corrosion Engineers SP0169, "Control of External Corrosion on Underground or Submerged Metallic Piping Systems," 2007 Edition.

- NFPA 22, "Standard for Water Tanks for Private Fire Protection," 2008 Edition.

\subsubsection{Potable Water and Sewer}

- IDAPA 58.01.03, 2009, "Individual/Subsurface Sewage Disposal Rules," Idaho Administrative Procedures Act, Idaho Department of Environmental Quality, July 2009.

- IDAPA 58.01.08, "Idaho Rules for Public Drinking Water Systems," Idaho Administrative Procedures Act, Idaho Department of Environmental Quality.

- Memorandum of Understanding between the Idaho Department of Environmental Quality and the Idaho Division of Building Safety Plumbing Bureau, April 2003.

- Uniform Plumbing Code, 2003 Edition. 


\subsubsection{Heating, Ventilating, and Air Conditioning and Ducting}

- ASHRAE 90.1, "Energy Standard for Buildings Except Low-Rise Residential Buildings," 2007 Edition.

- ASHRAE 55, "Thermal Environmental Conditions for Human Occupancy," 2004 Edition.

- ASHRAE 62.1, "Ventilation for Acceptable Indoor Air Quality," 2007 Edition.

- NFPA 90A, "Standard for the Installation of Air Conditioning and Ventilating Systems," 2009 Edition.

- NFPA 90B, "Standard for the Installation of Warm Air Heating and Air Conditioning Systems."

- IDAPA 07.07.01, "Rules Governing Installation of Heating, Ventilation, and Air Conditioning Systems, Division of Building Safety," Idaho Administrative Procedures Act, Idaho Department of Environmental Quality.

\subsection{Fire Protection}

\subsubsection{National Fire Protection Association}

- Factory Mutual (FM) 2-0, "Installation Guide for Automatic Sprinklers," 2011.

- FM 2-8, "Earthquake Protection for Water-Based Fire Protection Systems," 2010.

- FM 3-10, "Installation/Maintenance of Fire Service Mains," 2000.

- FM 3-26, "Fire Protection Water Demand for Nonstorage Sprinklered Properties," 2011.

- NFPA 1, "Fire Prevention Code," 2012 Edition.

- NFPA 10, "Standard for Portable Fire Extinguishers," 2010 Edition.

- NFPA 13, "Standard for the Installation of Sprinkler Systems," 2010 Edition.

- NFPA 14, "Standard for the Installation of Standpipe, Private Hydrant, and Hose Systems," 2010 Edition.

- NFPA 20, "Standard for the Installation of Stationary Pumps for Fire Protection," 2010 Edition.

- NFPA 22, "Standard for Water Tanks for Private Fire Protection," 2008 Edition.

- NFPA 24, "Standard for the Installation of Private Fire Service Mains and Their Appurtenances," 2010 Edition.

- NFPA 25, "Standard for the Inspection, Testing and Maintenance of Water Based Fire Protection Systems," 2011 Edition.

- NFPA 30, "Flammable and Combustible Liquids Code," 2012 Edition.

- NFPA 37, "Standard for the Installation and Use of Stationary Combustion Engines and Gas Turbines," 2010 Edition.

- NFPA 54, "National Fuel Gas Code," 2011 Edition.

- NFPA 55, "Standard for the Storage, Use, and Handling of Compressed Gasses and Cryogenic Fluids in Portable and Stationary Containers, and Tanks," 2010 Edition.

- NFPA 70, "National Electrical Code," 2011 Edition.

- NFPA 70E, "Standard for Electrical Safety in the Workplaces," 2012 Edition.

- NFPA 72, "National Fire Alarm and Signaling Code," 2010 Edition. 
- NFPA 75, "Standard for the Protection of Electronic Computer/Data Processing Equipment," 2009 Edition.

- NFPA 77, "Recommended Practice on Static Electricity," 2007 Edition.

- NFPA 79, "Electrical Standard for Industrial Machinery," 2012 Edition.

- NFPA 80, "Standard for Fire Doors and Fire Windows," 2010 Edition.

- NFPA 80A," Recommended Practice for Protection of Buildings from Exterior Fire Exposures," 2012 Edition.

- NFPA 90A, "Standard for the Installation of Air-Conditioning and Ventilating Systems," 2012 Edition.

- NFPA 90B, "Standard for the Installation of Warm Air Heating and Air-Conditioning Systems," 2012 Edition.

- NFPA 101, "Life Safety Code," 2012 Edition.

- NFPA 110, "Standard for Emergency and Standby Power Systems," 2010 Edition.

- NFPA 170, "Standard for Fire Safety Symbols," 2012 Edition.

- NFPA 220, "Standard on Types of Building Construction," 2012 Edition.

- NFPA 221, "Standard for Fire Walls and Fire Barrier Walls," 2012 Edition.

- NFPA 232, "Standard for the Protection of Records," 2012 Edition.

- NFPA 262, "Standard Method of Test for Flame Travel and Smoke of Wires and Cables for Use in Air-Handling Spaces," 2011 Edition.

- NFPA 780, "Standard for the Installation of Lightning Protection Systems," 2011 Edition.

- NFPA 801, "Standard for Fire Protection for Facilities Handling Radioactive Materials," 2008 Edition.

- NFPA 1144, "Standard for reducing Structure Ignition Hazards from Wildland Fire," 2008.

\subsection{Electrical}

\subsubsection{General Facility Electrical Codes and Standards}

- NFPA 70, "National Electric Code (NEC)," 2011 Edition.

- NFPA 70E, “Electrical Safety Requirements for Employee Workplaces,” 2009 Edition.

- Institute of Electrical and Electronics Engineers (IEEE)-C2, "National Electrical Safety Code," 2007 Edition.

- DOE-HDBK-O 420.1, DOE Handbook, "Design Considerations."

- DOE-HDBK-1092, DOE Handbook, “Electrical Safety,” 2004 Edition.

- DOE-HDBK-1132, DOE Handbook, "Design Considerations," 1999 Edition.

\subsubsection{Normal Power System Codes and Standards}

- IEEE-STD 141, "IEEE Recommended Practice for Electric Power Distribution for Industrial Plants," Red Book, 1993 Edition (R1999).

- IEEE-STD 242, "IEEE Recommended Practice for Protection and Coordination of Industrial and Commercial Power," Buff Book, 2001 Edition with Errata. 
- IEEE-STD 493, "IEEE Recommended Practice for the Design of Reliable Industrial and Commercial Power Systems," Gold Book, 2007 Edition.

- IEEE-STD 739, “IEEE Recommended Practice for Energy Management in Commercial and Industrial Facilities," 1995.

- IEEE-STD C57.12.00, "IEEE Standard General Requirements for Liquid-Immersed Distribution, Power, and Regulating Transformers," 1988.

- UL-508A, "Industrial Control Equipment," 2001 Edition with Revision.

- International Electrical Testing Association NETA-ATS, International Electrical Testing Association, "Acceptance Testing Specifications for Electrical Power Distribution Equipment and Systems," 2009 Edition.

\subsubsection{Lighting System Codes and Standards}

- $\quad 40$ CFR 261.24, "EPA Toxicity Characteristic Leaching Procedure (TCLP)," Code of Federal Regulations, Office of Federal Register.

- NFPA 101, "Life Safety Code," 2012 Edition.

- IESNA, "Lighting Handbook."

- ASHRAE 90.1, "Energy Standard for Buildings," 2007 Edition.

\subsubsection{Grounding System Codes and Standards}

- IEEE-80, "IEEE Guide for Safety in AC Substation Grounding," 2000 Edition with Errata.

- IEEE-STD 142, "IEEE Recommended Practice for Grounding of Industrial and Commercial Power Systems," Green Book, 2007 Edition.IEEE-1050, "IEEE Guide for Instrumentation and Control Equipment Grounding in Generating Stations," 2004 Edition.

- IEEE-1100, "Recommended Practice for Powering and Grounding Sensitive Electronic Equipment," Emerald Book, 2005 Edition.

- NFPA 77, "Recommended Practice on Static Electricity," 2007 Edition.

\subsubsection{Lightning Protection System Codes and Standards}

- NFPA 780, "Standard for the Installation of Lightning Protection Systems," 2011 Edition.

- UL-96A, "Installation Requirements for Lightning Protection Systems," 2007 Edition.

\subsubsection{Telephone System Codes and Standards}

- ANSI/TIA/EIA 568 C.0, "Generic Telecommunications Cabling for Customer Premises," 2010 Edition.

- ANSI/TIA/EIA 568 C.1, "Commercial Building Telecommunications Cabling Standard," 2010 Edition.

- ANSI/TIA/EIA 568 B.2, "Twisted Pair Cabling Components Standard," 2009 Edition.

- ANSI/TIA/EIA 568 B.3, "Optical Fiber Cabling Components Standard," 2008 Edition.

- ANSI/TIA/EIA 569 A, "Commercial Building Standards for Telecommunications Pathways and Spaces," 2004 Edition.

- ANSI/TIA/EIA J-STD-607, "Commercial Building Grounding and Bonding Requirements for Telecommunications," 2002 Edition.

- IEEE-802.3an, "IEEE Standard for Information Technology," 2006

- STD-170, "Information Management Infrastructure Standards," Idaho National Laboratory, 2011. 